\title{
Proceeding
}

Supplementary Issue: Spring Conferences of Sports Science. 15th Convention and Workshop of the International Network of Sport and Health Science, 5-8 June 2019. University of Las Palmas de Gran Canaria, Las Palmas de Gran Canaria, Spain.

\section{Inside Slavia's supporters: Fans who control the football matches in Czechia}

\author{
PETR SCHOLZ1 ${ }^{1}$, TOMAS VESPALEC ${ }^{2}$ \\ ${ }^{1}$ College of Polytechnics, Jihlava, Czech Republic \\ ${ }^{2}$ Faculty of Sports Studies, Masaryk University, Czech Republic
}

\begin{abstract}
Purpose: The goal of this paper is to analyse the relationship between supporters' verbal and other expression and their violent behaviour at selected football stadiums in Czechia. Methods: Primary data were collected by a questionnaire survey mainly at the Eden stadium in Prague in 2015/2016 and 2016/2017 seasons. A total of 158 respondents (aged $23.01 \pm 10.11$ years old) participated in this research, and all of the respondents were attending in a stand of home team supporters. Results: We found that expressions of demolishing the stadium and other disturbances are considered the most serious expression of violent behaviour by $56.96 \%$ of the supporters. On the other hand, $15.19 \%$ of the supporters had some experience with demolishing the stadium. Furthermore, $87.34 \%$ of the supporters stated that boo is the least serious problem, and almost every supporter (94.94\%) had an experience with booing the referee. Conclusions: Based on the results of the research, we find that younger supporters were more tolerant of negative social phenomena in the surroundings of the stadium. Keywords: Aggression; Behaviour; Supporters; Violence.

Cite this article as:

Scholz, P., \& Vespalec, T. (2019). Inside Slavia's supporters: Fans who control the football matches in Czechia. Journal of Human Sport and Exercise, 14(4proc), S818-S829. doi:https://doi.org/10.14198/jhse.2019.14.Proc4.44
\end{abstract}

Corresponding author. Masaryk University, Faculty of Sports Studies, Kamenice 5, 62500 Brno. Czechia.

E-mail: vespalec@fsps.muni.cz

Supplementary Issue: Spring Conferences of Sports Science. 15th Convention and Workshop of the International Network of Sport and Health Science, 5-8 June 2019. University of Las Palmas de Gran Canaria, Las Palmas de Gran Canaria, Spain. JOURNAL OF HUMAN SPORT \& EXERCISE ISSN 1988-5202

(c) Faculty of Education. University of Alicante doi:10.14198/jhse.2019.14.Proc4.44 


\section{INTRODUCTION}

Stroeken (2002) states that nowadays, football is more than just sport. It has become a public entertainment, in TV broadcasting it gets more and more space and time, primarily when two nations compete with each other. In 2018, a record audience of more than 3.5 billion viewers - more than half of the global population aged four and over - watched the World Cup in Russia (fifa.com). On the other hand, this beautiful game has a dark side: corruption, homophobia, violence, and racism.

For many years, the behaviour of football active fans has been the main subject of interest across Europe, especially in Germany, the Netherlands, Italy, and Belgium as well as in Great Britain. Violent and antisocial behaviour among football fans can also be labelled as a British or English disease (Cashmore \& Cleland, 2014; Frosdick \& Marsh, 2005; Williams, 2013). Therefore, it is essential to distinguish individual visitors to football matches (spectators, fans, supporters, and hooligans).

Unfortunately, frequent ignorance and misunderstanding of football hooliganism determine preview on it. It is crucial to distinguish hooligans from other people who are interested only in football and watch football matches (Scholz, 2016). In this context, it is possible to use the most common division and identify four major groups: inactive spectators, football fans, supporters, and hooligans (Sekot \& Smolík, 2009).

a) Inactive (objective) spectators. In this group there are four subgroups: (1) irregular visitors of the football matches, frequently this is a particular type of fashion and snobbery, (2) fans of the other clubs, not teams that are currently playing a football match (3) observers, coaches or other football players from other clubs, and (4), women (especially older ages), who attend the match as the accompanying persons of their partners, or children accompanying their parents. Mareš et al. (2004) state that spectators are passive observers of the game, they are not affected by the rivalry of the two teams, and thus, the game looks entirely neutral. They are not interested only in football matches, but they visit other sports games and other sports. Often they are not identified with a particular club and do not wear their symbols such as scarfs, caps, etc. The spectators are not always present at the football stadiums, and sometimes they watch the football match via the internet, television, etc. The TV allows to zoom in on details of individual chances, to slow the movement of players, to repeat tense situations and goals, to provide interviews, etc., which is not possible for the spectators at the stadium. On the other hand, television viewers are deprived of the atmosphere at football stadiums, which is created as an immediate reaction to the development of the game. Television can also contribute to a change in the structure of visitors who watch football matches at the stadium (Slepička et al., 2010).

b) Classical football fans ("normal"). These individuals attend football games and regularly have a relationship with their club, often due to the stadium being located relatively close to the place of their residence. A fan has certain expectations for development of the match, identifies with the team and therefore takes its success, or lack of it, personally (Greenwood et al., 2006; Slepička, 1990). Fans associated with the club usually invest most of their free time, energy, and money in their favourite football club (Wann \& Branscombe, 1993; Yusoff, 2016). Football is usually the only favourite sport for a football fan. Fans' identification is presented mainly by clothing, jerseys, club scarves, caps, T-shirts, flags, badges, etc. A division into "we" (supporters club) and "they" (fans of other clubs) is characteristic for fans; Slepička, 1990).

According to Gibbons \& Nuttall (2017) and Hunt et al. (1999), the fan's identity with the team, as well as the loyalty of the brand, is mostly considered to be strong and positive support for football teams. In sport, especially football, visitors can become loyal fans to the club they visit. Often, they become fanatic fans who 
rarely omit a home match (Thorne \& Bruner, 2006). According to Dwyer \& Kim (2011), fans are motivated by various factors, including gaining knowledge, social interaction, excitement, and enjoyment of gambling and sports betting. A high level of identification with the club is linked to the aspects as mentioned above, also with higher attendance (Fisher \& Wakefield, 1998). As Brandes et al. state (2013), in England, every fan purchases a season ticket, as tickets to individual matches are not available. As for other aspects, it is also an increased amount of funds spent on the club (Bernache-Assollant et al., 2007), more frequent purchases of merchandising and souvenirs (Kwon \& Armstrong, 2002) and, last but not least, more significant viewership on television or internet (Fisher, 1998).

c) Supporters (ultras). These persons create a highly homogeneous group of fans who strive for the most spectacular development of the match while avoiding direct conflict, violence, and vandalism. They are bearers of choreography in the game, often using fireworks, banners, and singing for cheering (Sekot, 2013). They much enjoy every game and are interested in the club's life. During the match, we can find them on the side stands behind the goals (ends), which are designed mostly for standing. Almost every supporter is dressed in a club jersey, a t-shirt, or owns at least a scarf of his favourite team (Scholz, 2016).

Their support is well organized, and sometimes it is possible to hear the militant support of their team. For supporters, a sign of devotion is to travel with the team to an international match (Guschwan, 2012). The atmosphere is an essential component and should be experienced on the day of the match. Some supporters say they are not so disappointed with a potential loss, but the atmosphere has to be unique (Edensor, 2014). We can state that there is a significant community of supporters in Poland and the atmosphere at football stadiums has become one of the best supporter communities in the world. Polish football was not affected by the dramatic process of commercialization eliminating supporters from the lowest social class. Consequently, the Polish supporters express and share their views through choreographies on various and non-football themes (Kossakowski et al., 2017).

Many supporter groups consist of people who have enough knowledge and experience of football, club, and players. Besides, these groups include individuals who did or are still doing top-level sports and people with a wide range of skills and knowledge (Nesti, 2010). Hunt et al. (1999) state that identification with the club is unique for supporters. Some supporters strongly associated with the club show signs of behaviour that is judged as inappropriate, unlawful, and may even lead to death (Wakenfield \& Wann, 2006). From such behavioural manifestations, some form of aggression and a willingness to engage in aggressive behaviour can be noticed. We can say that the higher the identification with the club, the more it is associated with the supporter's aggression (Wann, 1993). If a favourite team loses and the supporters are not happy with the game, they are considering an anonymous act through aggression or violent acts (Wann et al., 2003; Wann et al., 2005). As Bensimon \& Bodner (2011) claim, a more significant increase in aggression can be observed at the end of the football matches. They also say fans, who support their clubs are more susceptible to aggression than those who do not. Yusoff (2015) states if the supporters are truly dedicated to the club, they should learn to be more patient, bring a positive attitude to the stands, and not be provoked to unwanted behaviour from an opponent. Also, according to the general support with vocal cords or choreographies, pyrotechnics are used in most matches. Although pyrotechnics is forbidden at football stadiums in Czechia, supporters will be able to smuggle it into individual sectors in the end and then use it. They believe that pyrotechnics belong to football, especially concerning the bengal fires, which illuminate the atmosphere.

d) Hooligans (rowdies). They come to football stadiums and their surroundings with the primary objective to cause conflict or fight with the other similar groups from the opposing team. These groups (gangs) have their names, which are defined against unorganized groups and to other groups. Some of these parts are very 
well organized and do not unite only club rivalry and hatred of the enemy groups, but also political, racial, religious, national, regional, or social motives. Hooligans, unlike fans, often do not identify with a football club, but only with their group (Mareš et al., 2004).

Hooligans are referred to as predominantly youth subculture, which is associated with socially pathological phenomena. Football hooligans are associated in groups of mostly young militant "active fans." They come to football stadiums or their surroundings with the primary objective of provoking a conflict or a clash with other similar groups of the opponent's team (Mareš et al., 2004). The clash is nicknamed the "third halftime" among the active fans. It is not important whether their football club wins or loses (Kuru, 2000), hooligans are instead trying to stir the fuss (Kerr \& Kock, 2002) and damage the environment (Sahin, 2003). Hooligans also show their masculine pride by a choir singing and their determination to defend their honour with their fists. Besides, they share a refusal attitude towards the commercialization of the game, which binds the ability of these men to express their solidarity with other men in the group by choral singing and celebrations (King, 2000). Hooligan girl clashes, mostly in Russia, are also no exception (Scholz, 2018).

Spaaij (2008) presents six basic universal features that appear in the identity of hooligans: (1) adrenaline and pleasant emotional excitement, (2) hard masculinity, (3) identification with the territory, (4) individual and collective building of the gang's good name, (5) a sense of solidarity and belonging, and (6) a sense of representation, sovereignty and autonomy. There is a lot of prejudice and confusion about hooligans that are often strengthened by the media. In particular, tabloid journals focus on incidents, complemented by sensational headlines (Scholz \& Vespalec, 2017). Regularly, the media engages in inaccuracies and constructs reality. Smolík (2012) notes if the media do not change the approach when describing the tense games and continue to present this issue in a non-objective way, they can be in their way participating in those violent clashes and other riots.

During the 1970s and 1980s, it was not easy to provoke a direct fight at a stadium between groups and to steal, e.g., the flag of an opponent's cooperative in the end (King, 1997). Therefore, the hooligans had to choose another strategy (Smolik, 2008). During this period, they began to wear expensive brand clothing (most often Adidas, Aquascutum, Burberry, Fila, Lacoste, Lyle and Scott, Nike, Sergio Tacchini, Stone Island, etc.). These were no replicas of jerseys that became typical for new fans in the 1990s. In the event of a fight, the hooligans blended with the crowd, and it was not possible to determine whether they were football supporters (Frosdick \& Marsh, 2005; King, 2000). Also, they were given access to pubs where club clothing was not allowed. The police kept looking around and waited for the skinheads in the "Martens" and ignored people wearing luxurious clothes. Back in the 1960s, these shoes, the traditional English brands Dr. Martens, were discovered by Skinheads supporters who had realized their good potential for a clash with an opponent. Originally, these shoes were used mainly as orthopaedic footwear for middle-aged women (Smolík, 2008).

\section{METHODS}

Primary data were collected by a questionnaire survey mainly at the Eden stadium in Prague (home for Slavia Prague football club) in 2015/2016 and 2016/2017 seasons. A total of 720 persons aged $25.46 \pm 10.19$ years participated in this research. These were 592 men ( $25.62 \pm 10.20$ years), 120 women ( $25.01 \pm 10.20$ years), and eight persons did not wish to specify their gender. The research sample consisted of fans (462), supporters (158), sports spectators (68), and hooligans (32). All the respondents were attending in a stand of home team supporters. It is understandable that most of the respondents were among fans and supporters, as these two groups watch and support players directly from the stand behind the goal. That is where the supporters can be found in most of the cases. The same applies to hooligans, who usually occupy the first 
couple of rows behind the goal. In addition to the groups as mentioned above, the stand behind the goal was also visited by 68 sports spectators. We know it is a significantly lower number than for fans or supporters, but we have to note that sports spectators usually do not get the tickets for this part of the stadium. These persons like to watch a football match from the central or opposite stand that offers the best view and where they can enjoy the game.

In this paper, we shall focus on supporters only. The goal of the paper is to analyse the relationship between supporters' verbal and other expression and their violent behaviour at football stadiums in Czechia. The selection of respondents was based on carefully pre-defined factors; e.g., seats 1, 3, 5, 7 in the first row; seats 2, 4, 6, 8 in the second row, etc. from all the rows. It was a random selection. The respondents were informed about the research and anonymity of the questionnaire. Once they answered the questionnaires, each of them received a small Slavia club badge. They also had the opportunity to contact the interviewer via email stated on the questionnaire list and got themselves informed about the research results. The respondents were willing to participate in the research and were even entertained by filling out the questionnaires before the match started. The questionnaire consisted of twenty-nine questions; some of them were scalable, where respondents rated on a Likert scale (1-5) individual verbal and other expression and also their violent behaviour speeches. The least serious activity was rated 1; the most significant activity received the highest grade, i.e., 5. This paper uses methods of scientific work; and, i.e., the analysis method (also Correspondence analysis - CA), a method of generalization, mathematical, and statistical methods. Using graphic tools of this $\mathrm{CA}$, it is possible to describe an association of nominal or ordinal variables and to obtain a graphic representation of a relationship in multidimensional space - for the readers; it is easier to understand. The analysis provides further evidence that dependencies exist between variables.

CA is a multivariate statistical technique. It is conceptually similar to principal component analysis but applies to categorical rather than continuous data. In a similar manner to principal component analysis, it provides a means of displaying or summarizing a set of data in a two-dimensional graphical form (Zámková \& Prokop, 2014). All data should be non-negative and on the same scale for $C A$ to be applicable, and the method treats rows and columns equivalently. It is traditionally applied to contingency tables - CA decomposes the chisquared statistic associated with this table into orthogonal factors. The distance among single points is defined as a chi-squared distance. The distance between $i$-th and $i$ '-th row is given by the formula

$$
D\left(i, i^{\prime}\right)=\sqrt{\sum_{j=1}^{c} \frac{\left(r_{i j}-r_{i^{\prime} j}\right)^{2}}{c_{j}}}
$$

where $r_{i j}$ are the elements of row profiles matrix $R$ and weights $c_{j}$ are corresponding to the elements of column loadings vector $c^{\top}$, which is equal to mean column profile (centroid) of column profiles in multidimensional space. The distance between columns $j$ and $j$ ' is defined similarly, weights are corresponding to the elements of the row loadings vector $r$ and sum over all rows. In correspondence analysis, we observe the relation among single categories of two categorical variables. Result of this analysis is the correspondence map introducing the axes of the reduced coordinates system, where single categories of both variables are displayed in graphic form. The aim of this analysis is to reduce the multidimensional space of row and column profiles and to save maximally original data information. Each row and column of correspondence table can be displayed in $c$-dimensional ( $r$-dimensional respectively) space with coordinates equal to values of corresponding profiles. The row and column coordinates on each axis are scaled to have inertias equal to the principal inertia along that axis: these are the principal row and column coordinates (Hebák, 2007). 


\section{RESULTS AND DISCUSSION}

As far as individual groups of football visitors are concerned, we can say that the age structure was approximately the same, in the group of supporters and hooligans, the average age was three years lower.

It is evident from CA that the spectators in the Slavia end, were most often 34 years or over, the fans were 10-17 years old, supporters were most often 18-25 years old, and the hooligans 26-33 years old (figure 1).

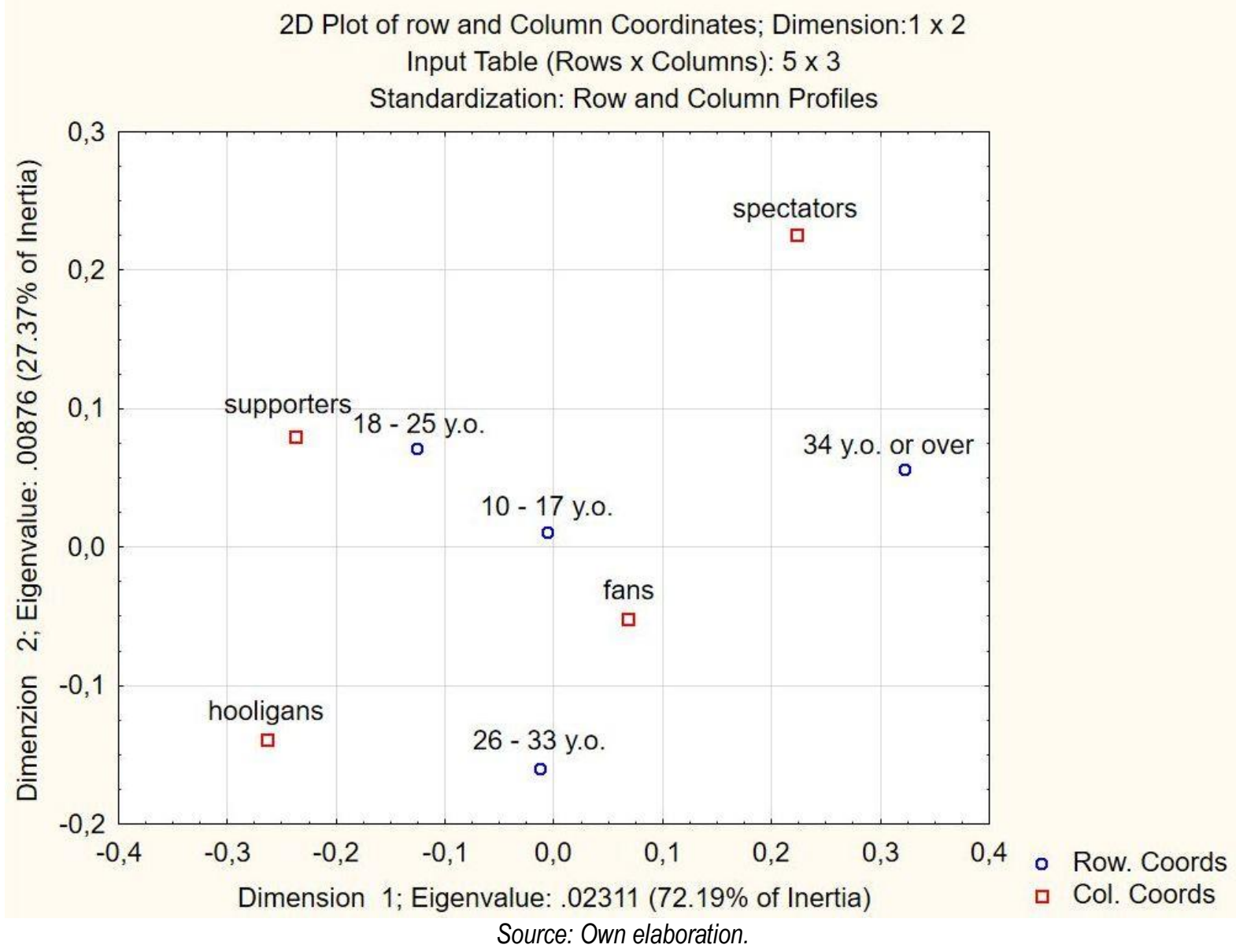

Figure 1. Age composition of visitor groups

a) Social and demographic statistics. More than $3 / 4$ of supporters $(87.71 \%)$ were single. We can state that this is a perfectly logical order concerning their age. It is an imitation of the social situation, where today's trend is to postpone the marriage only at a later age. Almost one-half of Individual supporters (46.84\%) lived with parents. Furthermore, we noted a tremendous response in cohabitation with a partner/spouse or married $(20.25 \%)$. The significant number of responses was also reported for supporters who live alone $(26.58 \%)$. More than $3 / 4$ supporters $(82.28 \%$ ) came from a full family.

An equally important fact, which is often mentioned in connection with the atmosphere at football stadiums, is the composition of the achieved education in the surveyed supporters. More than $1 / 3$ of surveyed supporters (35.44\%) received a high school diploma as well as more than $13.92 \%$ of supporters received the 
university diploma. $21.52 \%$ of supporters successfully passed a practical exam and received an apprenticeship certificate.

The most frequent "employment" among surveyed supporters was dominated by students $(51.90 \%)$, then self-employed (3.80\%), the position of the manager $(2.53 \%)$ and the waitress/waiter $(2.53 \%)$. Nearly half of supporters (44.12\%) actively played football. If we wanted to be more specific about active sports in football, $53.66 \%$ of them played the district championship, then less than a tenth of supporters $(9.76 \%)$ played the Hanspaulská league, the regional championship (7.32\%) and the junior 1 st league $(2.44 \%)$. In addition to football, supporters in the Czech Republic had a relationship with other sports - floorball (16.22\%), running, fitness and hockey (10.81\% each).

We noted that almost half of supporters (49.37\%) were satisfied with their lives, and another $40.51 \%$ of supporters were rather satisfied. In addition to being content with their lives, supporters also subjectively assessed their economic situation. Supporters were even satisfied in $70.89 \%$ of cases.

b) Supporters' participation in the activities during the football matches. Almost every supporter (98.73\%) owned a scarf, jersey, or T-shirt. Regarding the emotional response of the watched game, the results were as follows: over one-third of the supporters (84.81\%) were excited throughout the football match, next $15.19 \%$ were excited occasionally.

Negative feelings frequently evoke the level of a football match $(78.48 \%)$, controversial decisions of referees $(69.62 \%)$, unsporting behaviour of spectators $(11.39 \%)$, and unsporting behaviour of players and coaches $(11.39 \%)$. Over one-third of the supporters $(37.97 \%)$ regretted the loss of the club only immediately after the end of the match, only $5.06 \%$ of the supporters did not care about the loss of the club. If the match is broadcast on TV, over $2 / 3$ of the supporters (70.89\%) opted for watching it at the football match at the stadium. The rest of the supporters $(29.11 \%)$ sometimes visited the football match; sometimes they watched the football match from the sofa. The reasons for not going to the football stadium are the lack of money, afternoon or night shift at work, and the lack of time. Over $3 / 4$ of the supporters $(75.95 \%)$ consciously never took an object to the football stadium which could be used as a weapon. Only $20.25 \%$ of the supporters had a different opinion about this activity and some objects used as weapons (e.g., a flagstick, bottle of water or even a brick from the newspaper - known as a "Millwall brick"). Almost 1/2 of the supporters (49.37\%) sometimes participated in the firing of pyrotechnics. They agreed with the expression of the supporters, "no pyrotechnics no party." The same percentage of the supporters did not participate in pyrotechnics, and the rest of the supporters $(1.26 \%)$ had a different point of view and used the pyrotechnics every match. Over one-half of the supporters (54.43\%) sometimes expressed vulgarly.

Almost one-half of the supporters (44.31\%) used vulgar expressions every football match. Such expressions are mostly addressed to the Head of the Football Association of the Czech Republic and the Head of the referee committee; also to the referees and some players of the rival team, who react negatively to Slavia Prague. Vulgarisms are part of the behaviour typical for supporters. Only $1.26 \%$ of the supporters did not use vulgarisms.

Over $1 / 4$ of the supporters $(26.58 \%$ ) never drink alcohol before or during the football match. Over $1 / 3$ of the supporters (40.51\%) sometimes drink at the football stadium and the rest of the supporters (32.91\%) always drink alcohol. Currently, the stadiums only sell non-alcoholic beer during the matches of European League, derby or other risky matches. Almost one-fifth of the supporters $(15.19 \%)$ had some experience with demolishing the stadium and other riots. The rest of the supporters (84.81\%) did not have this experience. 
Racism is one of the most discussed topics all over the world among football managers, top officials, players, fans, etc.

Over one-half of the supporters (58.23\%) did not shout racist insults at black football players. Almost 1/3 of the supporters sometimes used racist insults during the football matches.

Booing from supporters are for three main reasons: the crowd disagrees with a foul the referee has called or not called; the crowd is holding a grudge against a particular player for some reason, and he or she has the ball; and the crowd feels a team is playing cynically through "simulating fouls" by diving or time-wasting or playing too passively by passing the ball backward excessively. Almost every supporter had an experience with boo the referee $(94.94 \%)$ and $92.41 \%$ of the supporters booed on the Head of the Czech Football Association, and $91.14 \%$ of the supporters booed on the rival players and club.

Over $1 / 3$ of the supporters $(36.71 \%)$ threw an object on the pitch. It is mostly caused by the false verdict by the line referee or at the rival's goal celebration in front of the various kinds of audience. The football pitch is often covered with empty or full plastic beer cups, coins or even lighters. We should consider that the referee decision should catalyse the violent clash, even in the situation when they do not behave in line with the football rules. Almost $1 / 2$ of the supporters (44.31\%) had experience with a pitch excursion (historical proceed to Champions League in 2007 and friendly match with the football team Hajduk Split in 2014).

Table 1. The participation of visitor groups in specific violations in percentage

\begin{tabular}{|l|r|l|r|}
\hline Pitch incursion & 44.30 & yes & \\
yes & 55.70 & no & 36.71 \\
no & & Booing the referee & 63.29 \\
\hline $\begin{array}{l}\text { always } \\
\text { sometimes }\end{array}$ & 1.27 & often & 44.30 \\
never & 49.37 & sometimes & 50.63 \\
Racism display & 49.37 & never & 5.07 \\
often & & Booing the rival players and the club & \\
sometimes & 10.13 & often & 63.29 \\
never & 31.65 & sometimes & 27.85 \\
Demolishing the & 58.23 & never & 8.86 \\
stadium & & Drinking alcohol & \\
often & 0.00 & always & 32.91 \\
sometimes & 15.19 & sometimes & 40.51 \\
never & 84.81 & never & 26.58 \\
Vulgar chants in the & & Bringing objects to the stand with an & \\
stand & & intention of using them as a weapon & \\
always & 44.30 & always & 3.80 \\
sometimes & 54.43 & sometimes & 20.25 \\
never & 1.27 & never & 75.95 \\
\hline
\end{tabular}

Source: Own elaboration.

c) Supporters' expressions on mentioned activities. The examined group of the supporters showed very similar opinions on the pyrotechnics. $67.09 \%$ of them considered using pyrotechnics the least serious 
problem. Supporters used pyrotechnics in many cases and brought them to the stadiums. As far as the vulgarity of the end and vulgar expressions usage, we reached approximately the same values. Over 1/4 of the supporters (25.32\%) considered physical aggression the most serious expression at the stadium. Agreed hooligans fight behind outside the stadium was mentioned by $55.70 \%$ of the supporters as the least serious activity. Furthermore, over $1 / 2$ of the supporters (56.96\%) stated that the stadium demolition and other riots do belong to the serious problems. It is interesting that the stadium demolition mostly happens at the rival's stadium.

Only $25.32 \%$ of the supporters are persuaded that the objects throwing on the pitch are the most serious activity. The booing was unanimously agreed as the least serious activity (87.34\%). Positively is a pitch incursion perceived as a wrong approach on the one hand or as a provocation on the other hand. Over $1 / 5$ of the supporters $(20.25 \%)$ consider the pitch incursion as the most serious expression (table 2 ).

Table 2. Supporters' expressions on mentioned activities in percentage

\begin{tabular}{|l|r|r|r|r|r|}
\hline \multicolumn{1}{|c|}{ Activities } & \multicolumn{1}{c|}{$\mathbf{1}$} & \multicolumn{1}{c|}{$\mathbf{2}$} & \multicolumn{1}{c|}{$\mathbf{3}$} & \multicolumn{1}{c|}{$\mathbf{4}$} & \multicolumn{1}{c|}{$\mathbf{5}$} \\
\hline firing of pyrotechnics & 67.09 & 21.52 & 7.59 & 2.53 & 1.27 \\
vulgar chants in the stand & 62.03 & 26.58 & 6.33 & 5.06 & 0.00 \\
\hline individual vulgar expression & 60.76 & 11.39 & 16.46 & 6.33 & 5.06 \\
physical aggression against rival fans at the stadium & 16.46 & 11.39 & 29.11 & 17.72 & 25.32 \\
physical aggression against police and riot police & 21.52 & 8.86 & 20.25 & 24.05 & 25.32 \\
arranged hooligan fight outside the stadium & 55.70 & 6.33 & 12.66 & 8.86 & 16.46 \\
throw in the object on the pitch & 11.39 & 18.99 & 26.58 & 17.72 & 25.32 \\
demolishing stadium and other riots & 6.33 & 7.59 & 12.66 & 16.46 & 56.96 \\
boos & 87.34 & 8.86 & 2.53 & 1.27 & 0.00 \\
pitch incursion & 24.05 & 15.19 & 22.78 & 17.72 & 20.25 \\
\hline
\end{tabular}

Source: Own elaboration.

Note. 1 - the least serious expression, 2 - less serious expression, 3 - neutral, 4 - rather serious expression, 5 - the most serious expression.

\section{CONCLUSIONS}

We state that the results are adequate for supporters. Based on the results of the research, we find that younger supporters are more tolerant of negative social phenomena in the surroundings of the stadium. The analysis indicated that expressions of demolishing the stadium and other disturbances are considered the most serious expression of violent behaviour by $56.96 \%$ of the supporters and $84.81 \%$ of the supporters did not have some experience with demolishing the stadium. Furthermore, $87.34 \%$ of the supporters stated that boo the least serious problem and almost every supporter $(94.94 \%)$ had an experience with boo the referee. Over $2 / 3$ of the supporters $(67.09 \%$ ) stated that firing of pyrotechnics is the least serious problem; other least serious activities were vulgar chants in the stand (62.03\%), and individual vulgar expression (60.76\%). The atmosphere is an essential component for supporters and should be the highlight during the football match. Some supporters say that the result is not so much important as especially the atmosphere which must be unique. 


\section{REFERENCES}

Bensimon M, Bodner E (2011) Playing with Fire: The Impact of Football Game Chanting on Level of Aggression. J Appl Soc Psychol 41(10): 2421-2433. https://doi.org/10.1111/i.15591816.2011.00819.x

Bernache-Assollant I, Bouchet P, Lacassagne M (2007) Spectators' Identification with French Sports Teams: a French Adaptation of the Sport Spectator Identification Scale. Percept Mot Skills 104(1): 83-90. https://doi.org/10.2466/pms.104.1.83-90

Brandes $L$, Franck E, Theiler $\mathrm{P}(2013)$ The group size and loyalty of football fans: a two-stage estimation procedure to compare customer potentials across teams. J R Stat Soc 176(part2): 347-369. https://doi.org/10.1111/j.1467-985X.2011.01033.x

Cashmore E, Cleland J (2014) Football's Dark Side: Corruption, Homophobia, Violence and Racism in the Beautiful Game. Basingstoke: Palgrave Macmillan. https://doi.org/10.1057/9781137371270

Dwyer B, Kim Y (2011) For Love or Money: Developing and Validating a Motivational Scale for Fantasy Football Participation. J Sport Manage 25(1): 70-83. https://doi.org/10.1123/ism.25.1.70

Edensor T (2014) Producing atmospheres at the match: Fan cultures, commercialisation and mood management in English football. Emot Space Soc 15: 82-89. https://doi.org/10.1016/i.emospa.2013.12.010

Fisher RJ (1998) Group-derived consumption: the role of similarity and attractiveness in identification with a favorite sports team. Adv Consum Res 25(1): 283-288.

Fisher RJ, Wakenfield K (1998) Factors leading to group identification: a field study of winners and losers. Psychol Mark 15(1): 23-40. https://doi.org/10.1002/(SICI)1520-6793(199801)15:1<23::AIDMAR3>3.0.CO;2-P

Frosdick S, Marsh P (2005) Football Hooliganism. Devon, United Kingdom and Portland, OR: Willan Publishing.

Gibbons T, Nuttall D (2017) 'True fan = watch match'? In search of the 'Authentic' soccer fan. Socc Soci 17(4): 527-539. https://doi.org/10.1080/14660970.2014.980735

Greenwood PB, Kanters MA, Casper JM (2006) Sport Fan Team Identification Formation in Mid-Level Professional Sport. Euro Sport Manage Q 6(3): 253-265. https://doi.org/10.1080/16184740601095016

Guschwan M (2012) Fandom, brandom and the limits of participatory culture. J Consum Cult 12(1): 1940. https://doi.org/10.1177/1469540512438154

Hebák P, Hustopecký J, Pecáková I, Prưša M, Rezanková H, Svobodová A, Vlach P (2007) Vícerozměrné statistické metody 3. Praha: Informatorium.

Hunt KA, Bristol T, Bashaw RE (1999) A conceptual approach to classifying sports fans. J Serv Mark 13(6): 439-452. https://doi.org/10.1108/08876049910298720

Kerr JH, Kock H (2002) Aggression, violence and the death of a Dutch soccer hooligan: A reversal theory explanation. Aggress Behav 28(1): 1-10. https://doi.org/10.1002/ab.90001

King A (1997) The postmodernity of football hooliganism. $\mathrm{Br} J$ Sociol 48(4): 576-593. https://doi.org/10.2307/591597

King A (2000) Football Fandom and Post-National Identity in the New Europe. Br J Sociol 51(3): 419442. https://doi.org/10.1080/00071310050131602

Kossakowski R, Szlendak T, Antonowicz D (2017) Polish ultras in the post-socialist transformation. Sport Soc 21(6): 854-869. https://doi.org/10.1080/17430437.2017.1300387

Kuru E (2000) Sporda Psikoloji. Ankara, Türkiye: Gazi University lletisim Publishing.

Kwon HH, Armstrong KL (2002) Factors influencing impulse buying of sport team licensed merchandise. Sport Mar Q 11(3): 97-109. 
Mareš M, Smolík J, Suchánek M (2004) Fotbaloví chuligáni: evropská dimenze subkultury. Brno, Czechia: Centrum strategických studií a Barrister \& Principal.

Nesti M (2010) Psychology in Football. London, United Kingdom and New York, NY: Routledge. https://doi.org/10.4324/9780203874585

Sahin M (2003) Gaziantep Futbol Takımı Taraftarlarının Şiddet Ve Saldırganlık Olaylarına Bakış Açılarının Sosyolojik Ve Psikolojik Boyutu Üzerine Bir Araştırma. Gaziantep, Türkiye: Gaziantep Sports Club Education Publishing.

Scholz P (2016) Czech Football Hooligans' Behavior. J Phys Educ Sport 16(suppl.2): 1089-1094.

Scholz P (2018) Problematika fotbalového diváctví v České republice aneb quo vaditis, fotbaloví př́znivci? Brno, Czechia: Paido.

Scholz P, Vespalec T (2017) Comparación de hinchas y hooligans en República Checa: El ejemplo del club de fútbol Slavia Praga. Sport TK Rev EuroAm Cien Dep 6(1): 125-130. https://doi.org/10.6018/280531

Sekot A (2013) Sociologie sportu: aktuální problémy. Brno, Czechia: Masaryk University.

Sekot A, Smolík J (2009) Sportovní fanoušek ve fotbalovém kotli. Stu Sport, 3(1): 77-94.

Slepička P (1990) Sportovní diváctví. Prague, Czechia: Olympia.

Slepička P, Slepičková I, Kotlík K, Landa P (2010) Divácká reflexe sportu. Charles University in Prague, Czechia: Karolinum.

Smolík J (2008). Fotbalové chuligánství - historie, teorie, a politizace fenoménu. Karlovy Vary, Czechia: Zdeněk Plachý.

Smolík J (2012) Football Hooligans in the Czech Republic: Selected Topics. Kult Społ Edu 1(2): 75-95. https://doi.org/10.14746/kse.2012.2.07

Spaaij R (2008) Men Like Us, Boys Like Them. Violence, Masculinity, and Collective Identity in Football Hooliganism. J Sport Soc Issues 32(4): 369-392. https://doi.org/10.1177/0193723508324082

Stroeken K (2002) Why 'The World' Loves Watching Football (And 'The Americans' Don't). Anthropol Today 18(3): 9-13. https://doi.org/10.1111/1467-8322.00119

The International Federation of Football Associations. Retrieved from http://fifa.com

Thorne S, Bruner GC (2006) An exploratory investigation of the characteristics of consumer fanaticism. Q Mark Res Int J 9(1): 51-72. https://doi.org/10.1108/13522750610640558

Wakenfield KL, Wann DL (2006) An examination of dysfunctional sport fans: method of classification and relationship with problem behaviors. J Leis Res 38(2): 168-186. https://doi.org/10.1080/00222216.2006.11950074

Wann DL (1993) Aggression among highly identified spectators as a function of their need to maintain a positive social identity. J Sport Soc Issues 17(2): 134-143. https://doi.org/10.1177/019372359301700207

Wann DL, Branscombe NR (1993) Sports fans: Measuring degree of identification with their team. Int J Sport Psychol 24(1): 1-17.

Wann DL, Haynes G, McLean B, Pullen P (2003) Sport team identification and willingness to consider anonymous acts of hostile aggression. Aggress Behav, 29(5): 406-413. https://doi.org/10.1002/ab.10046

Wann DL, Culver Z, Akanda R, Daglar M, De Divitiis C, Smith A (2005) The effects of team identification and game outcome on willingness to consider anonymous acts of hostile aggression. J Sport Behav 28(3): 282-294.

Williams AM (2013) Science and Soccer. Developing Elite Performers. New York, NY: Routledge. https://doi.org/10.4324/9780203131862

Yusoff NH (2015) Relationship between Situational Factors and Deviant Behaviour among Football Spectators in Malaysia. Int J Arts Comm 4(1): 27-33. 
Yusoff NH (2016) Types of Deviant Behavior among Football Fans in Malaysia. Mediterr J Soc Sci 7(1): 59-62. https://doi.org/10.5901/mjss.2016.v7n1s1p59

Zámková M, Prokop M (2014) Comparison of Consumer Behavior of Slovaks and Czechs in the Market of Organic Products by Using Correspondence Analysis. Acta Univ Agric Silvic Mendel Brun 62(4): 783-795. https://doi.org/10.11118/actaun201462040783

\section{(c) $(\mathrm{B})(\mathrm{EY}$}

This work is licensed under a Attribution-NonCommercial-NoDerivatives 4.0 International (CC BY-NC-ND 4.0). 